\title{
Science and technology for development: no escaping the politico-economic context
}

\begin{abstract}
Dr Narendra Singh, President of the Indian CSIR Scientific Workers' Association, argues that fundamental political problems must be solved before science and technology can make a contribution to development.
\end{abstract}

MANY scientists will first have heard of the United Nations Conference on Science and Technology for Development (UNCSTD), through Moravcsik's recent Nature article (24 November, page 288). "Will the voice of science in the Third World be heard?" I have basic differences with the elitist features in Moravcsik's article, but I agree with him that the scientists in Third World countries must seriously participate in the formulation of national papers and not leave the task to a small group of bureaucrats and technocrats. In the absence of broad participation, the basic issues may be missed altogether, with serious implications on the national scene and for cooperation among Third World countries.

Perhaps I should first discuss this elitism I have mentioned above. Moravcsik urges Third World scientists to make prompt and forceful inputs in three main areas for incorporation in the national papers, namely the special needs of foreign-educated indigenous scientists, the expansion of communication facilities and evolution of institutions dedicated to long term, not just immediate research, and the practice of science for the purpose of establishing more equality not just in GNP per capita but also in countries' self-images of their standing in the world of science. These points seem quite innocuous and may readily appeal to all concerned, but they do ignore the historical antecedents of industrially developed countries and the way in which science developed therein; they also ignore the present politico-economic context of the Third World countries. Such proposals make no contribution to socially useful science and technology for development in the Third World countries and would ultimately even fail to achieve their espoused purpose.

Take, for example, China. Without paternalistic advice and elitist and esoteric diversion, China has fruitfully applied science and technology to solve the immediate problems of its people and has also made important contributions on the frontiers of science. Fundamental science is the foundation of both immediate and long-term research, and is not incompatible with a balanced programme of science and technology for development. But first the basic political and economic objectives must be clear, and be actively pursued.

National papers of Third World countries should thus enunciate the basic objectives of science and technology for development and then identify areas of action for achieving those objectives. No doubt competent analyses could lead to the identification of obstacles such as the practices of corporations and monopolies, and to proposals that would decrease dependence. But for real progress towards self-reliance, much more than this is needed. It is vital to determine how to change the politico-economic context of operation of those forces which give rise to obstacles to progress. Unless that is done, we continue to grope in a maze, proliferating technology and management-oriented solutions to problems of science and technology for development, but to no avail, since the problems are essentially poltico-economic.
Take the case of science and technology for integrated rural development, a subject of great concern at present. The large-scale agro-industries, concentrating on single crops, are proliferating. They depend largely on technology imported from the developed world, and sell principally to local affluent markets and for export.

Such an analysis would frequently be followed by calls for appropriate technologies to decrease dependence, and experts would recommend a separate department of agroindustrial science and technology, the expansion of relevant activity in existing organisations, an integrated technical information centre and the strengthening of relevant technical facilities for appropriate agro-industries. Apparently sound suggestions. But what about those factors which have been promoting technological dependence? Unless there is action to check the operation of those factors, no practical progress is possible. Thus a programme for integral rural development must combine suggestions of measures for eliminating obstructive forces and creating a favourable environment for developments in positive directions together with concrete proposals on appropriate technologies.

The basic objectives of science and technology for development in the Third World countries are economic independence, self-sufficiency in basic needs of the common people and self-reliance in development. The forthcoming UN conference professes the aim of national self-reliance to the extent called for in the new international economic order. The qualifying phrase is unnecessary and is probably made to adjust Third World countries to the modern neocolonial international division of labour.

No real national self-reliance can be achieved in the politico-economic context of the modern world unless it is linked with the aims of economic independence and selfsufficiency in essentials. 'Economic independence' does not mean economic isolation, but a national capability for economic relations with others on equal terms and from a position of economic strength, instead of the present recipient-donor relation with the industrially developed countries.

'Self-sufficiency' in essentials, in food and others, is basic to economic independence of the Third World countries and to the welfare of the common people there, but this does not necessarily mean a self-sufficiency in each individual item all the time, only that in compelling circumstances there must be enough surplus of some items to trade for other items in need. Likewise, 'self-reliance' in development does not mean self-imposed isolation, but only national capabilities to be able to carry on development pursuits, including those in science and technology, even in the most adverse circumstances of enforced isolation.

The forthcoming UN conference must be oriented towards achieving real national self-reliance, which in turn is not possible without progress towards economic independence and self-sufficiency in basic essentials. The input in national papers must take the basic issues into account and develop them with concrete proposals, instead of mere concern with details of technology and organisation. And these basic issues must be raised for serious discussion at the conference, to encourage cooperation within the Third World and with industrialised countries. In my opinion, these issues are of real significance for Third World participants and must be of concern also to others who are sincere in their professions of an interest in science and development. 